\title{
VIDEO PROFILE PADA SMK KUSUMA BANGSA KABUPATEN TANGERANG SEBAGAI PENUNJANG INFORMASI DAN PROMOSI
}

\author{
Achmad Zainudin $\mathrm{MN}^{1}$ \\ Sutajaya $^{2}$ \\ Ajeng Retno Anggraeni ${ }^{3}$ \\ Dosen STMIK Raharja ${ }^{1}$, Magister Teknik Informatika STMIK Raharja ${ }^{2}$, STMIK Raharja Jurusan \\ Teknik Informatika ${ }^{3}$ \\ Jl. Jendral Sudirman No. 40, Modern Cikokol, Tangerang

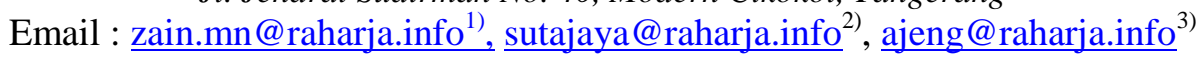

\begin{abstract}
ABSTRAK
Kemajuan suatu bangsa sangat dipengaruhi oleh kualitas sumber daya manusia masyarakat bangsa tersebut. Kualitas SDM tergantung pada tingkat pendidikan masing-masing individu pembentuk bangsa. SMK Kusuma Bangsa memiliki Fasilitas yang banyak dan memiliki cara belajar yang berbeda. Sehingga SMK Kusuma Bangsa memiliki keunggulan yang luar biasa, Berdasarkan hasil analisis data disimpulkan bahwa promosi melalui video dalam pengembangan mutu sekolah di SMK Kudums Bsngds Tangerang dilaksanakan dengan koordinasi yang baik melibatkan semua sumber daya yang ada di sekolah sehingga berhasil dalam pembuatan video profil sekolah tersebut (siswa, orang tua dan masyarakat) sehingga dapat memberikan pelayanan pendidikan yang bermutu.
\end{abstract}

Kata Kunci : Analisa, Informasi, Siswa

\begin{abstract}
Also new is a nation deeply influenced by the quality of the human resources community of the nation. Quality of human resources depends on the level of education of each of the elements accentuate Personality-forming nation. SMK Kusuma nation has many amenities and have a way of studying the fruit. So, THIS has the advantage that Nation Kusuma is incredible, based on the results of data analysis it was concluded that the promotion of quality in the development of video through school in SMK Tangerang Bsngds Kudums implemented with good coordination involves Rukan resources are there in school so successful in making the video profile of the school (students, parents and the community) so as to provide quality educational services.

Key Words: Analysis, Information, Students
\end{abstract}

\section{PENDAHULUAN}

Setiap tahun teknologi informasi memiliki peningkatan atau kemajuan yang tinggi, di dalam teknologi yang begitu tinggi dapat memudahkan masyarakat untuk mendapatkan informasi secara singkat dn cepat. Media informasi seperti Koran, radio dan TV, tetapi dunia informasi ternyata lebih cepat di dapat oleh masyarakat melalui media video atau TV. Dalam penelitian ini membuat video profil SMK Kusuma Bangsa yang berada di kabupaten tangerang.

\section{RUMUSAN MASALAH}

Banyak informasi yang di gunakan untuk mempromosikan suatu instasi pendidikan tetapi informasi tersebut kurangnya di ketahui oleh masyarakat sehingga informasi suatu pendidikan kurangnya dikenal masyarakat. Maka dari itu SMK Kusuma Bangsa 
Kabupaten Tangerang membuat video profile yang dimana video profle akan di promosikan melalui social media, di dalam kepingan DVD sehingga akan di bagikan ke calon SMK Kusuma Bangsa Kabupaten Tangerang. Dan pada pameran pendidikan.

\section{LANDASAN TEORI}

\section{Pengertian Media}

Sarana media komunikasi berbentuk Surat Kabar, Radio dan TV yang dimana dapat di lihat dan di dengar oleh masyarakat luas

\section{Pengertian Informasi}

Keputusan yang di berikan oleh seseorang dan ke masyarakat sehingga informasi tersebut menjadi meluas.

\section{Pengertian Video}

Suara dan Gambar yang dapat dilihat oleh masyarakat.

\section{Format Video}

Tahap akhir dalam editing pada saat menjadikan hasil file dari video tersebut, format hasil video tersebut diantaranya: AVI, MPEG-1, MPEG-2, MPEG 3, MPEG-4, MOV,ASF, WMV,AAC dll.

\section{Tahapan Produksi Audio Visual}

\section{Pra Produksi}

Langkah awal untuk mulai membuat suatau karya audio visual, memiliki tahapan-tahapan yang harus dilakukan diantaranya :

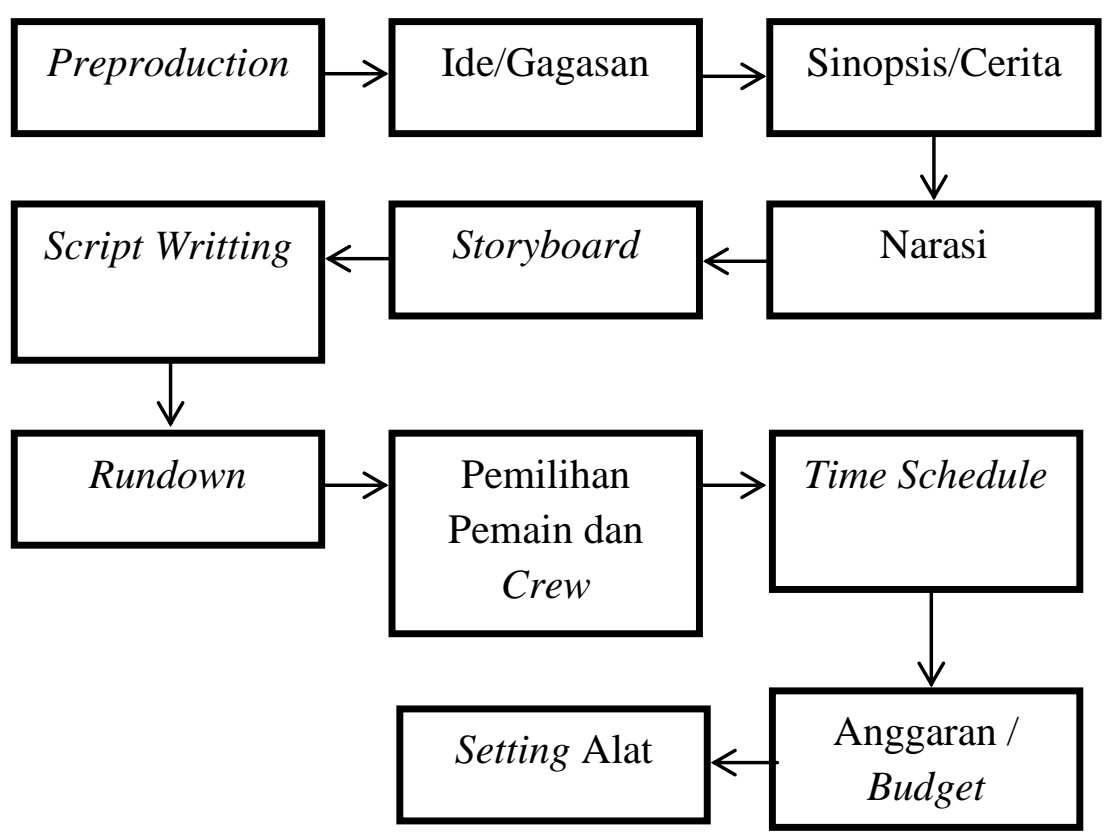

Gambar 1. Tahapan Pra Produksi 


\section{Produksi}

Setelah melakukan langkah awal selanjutnya produksi dimana produksi adalah membuat pengambilan gambar yang dimana harus di sesuaikan dengan storyboad agar pada saat pengambilan gambar tidak bangak mengalami kendala.

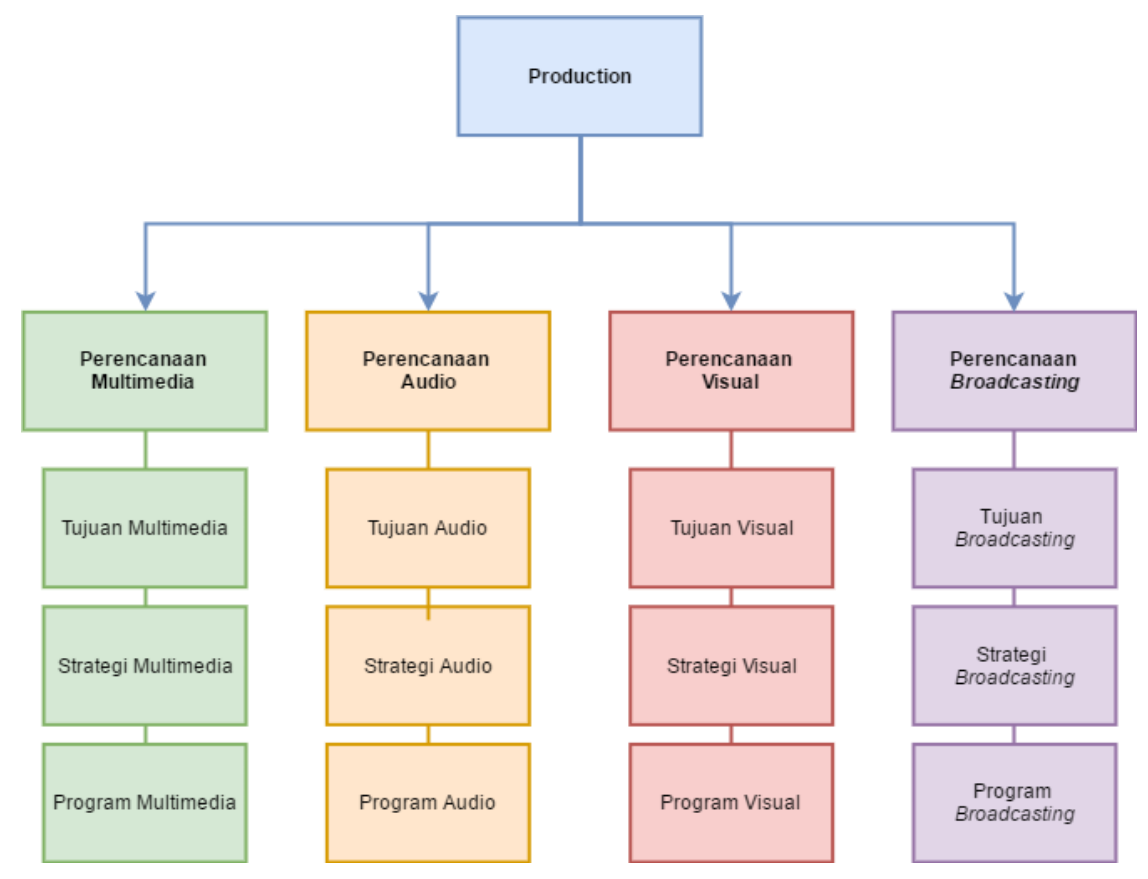

\section{Post Produksi}

Gambar 2. Tahapan Produksi

Post Produksi atau pasca produksi adalah langkah akhir yang menggunakan editing dan editing tersebut menggunakan aplikasi agar editing suatu video hasilnya akan rapih dan bagus.

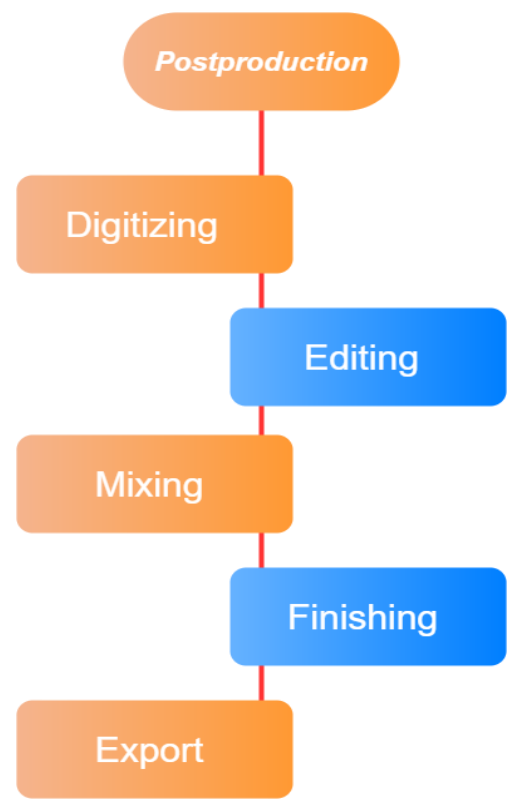

Gambar 3. Pasca Produksi 


\section{Storyboard}

Scene 1

Bumper Opening Tulisan SMK

Kusuma Bangsa

Gambar 4. Bumper Opening Tulisan SMK Kusuma Bangsa

\section{Scene 2}

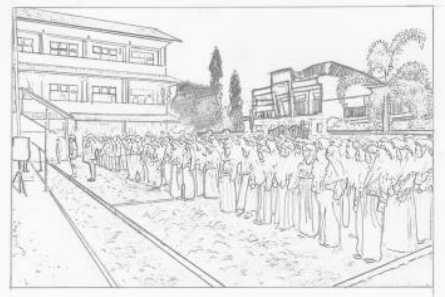

Gambar 5. EXT / video Upacara Bendera (Full Shoot)

Scene 3

EXT / Gedung Sekolah

(Medium Shoot)

Gambar 6. EXT / Gedung Sekolah (Medium Shoot)

Scene 4

video destinasi wisata

tanjung pasir (Fullshoot)

Gambar 7: video Visi dan Misi 
Scane 5

Ruang Kelas (Medium

Shoot)

Gambar 8. INT/ Ruang Kelas (Medium Shoot)

Scane 6

Gedung Sekolah (Medium

Shoot)

Gambar 9. EXT/ Gedung Sekolah (Medium Shoot)

Scane 7

Ruang Kelas (Medium

Shoot)

Gambar 10. INT/ Ruang Kelas (Medium Shoot)

Scane 8

Ruang Lab (Medium Shoot)

Gambar 11. INT/ Ruang Lab (Medium Shoot) 
Scene 9

\section{Ruang Diskusi (Medium}

Shoot)

Gambar 12. INT/ Ruang Diskusi (Medium Shoot)

\section{LITERATUR REVIEW}

a. Penelitian Yang Dilakukan Oleh Siti Salamah $(2011)^{[18]}$, Dengan Judul "Perancangan Video Profil Jurusan Teknik Informatika Jenjang Stara Satu Sebagai Penunjang Sarana Informasi Dan Promosi Pada Perguruan Tinggi Raharja "

Dunia Multimedia Dan Broadcasting Adalah Dunia Yang Sangat Akrab Dengan Hal Elekrtonika Dan Teknologi Canggih. Hal Ini Di Buktikan Dengan Perancangan Media Promosi Dan Informasi Yang Semakin Meningkat Mengikuti Tuntutan Perkembangan Teknologi Yang Begitu Pesat Dengan Adanya Media Informasi Yang Bervariatif Seperti Desain Komunikasi Visual, Dan Audio Visual Atau Yang Lebih Dikenal Dengan Videoadalah Sebuah Cerita Bergambar Yang Dapat Bergerak Dan Bersuara. Dimana Sebuah Video Dapat Menjelaskan Dan Menceritakan Hal-Hal Yang Ingin Di Informasikan Kepada Masyarakat Apa Dan Bagaimana Pesan Yang Ingin Disampaikan, Sehingga Masyarakat Dapat Mengerti Dan Memahami Apa Yang Ada Dalam Video Tersebut. Video Juga Dapat Menjadi Media Informasi Dan Promosi Yang Menunjang Sebuah Instansi Pendidikan Dalam Mempromosikan Program Studinya.Perguruan Tinggi Raharja Adalah Sebuah Instansi Pendidikan Yang Dituntut Untuk Mempunyai Media Penyampaian Informasi Yang Sangat Menarik Agar Dapat Diminati Banyak Orang.

b. Penelitian Yang Dilakukan Oleh Taufik Fikrei Fadhilah(2011) ${ }^{[19]}$, Berjudul "Pengembangan Video Profile Sebagai Media Penunjang Informasi Dan Promosi Pada Pt. Ariesta Steleyna".

Saat Ini, Perkembangan Komputer Di Bidang Multimedia Membantu Manusia Di Abad Ini Untuk Dapat Saling Berinteraksi Dengan Lebih Baik. Dengan Multimedia Manusia Memiliki Berbagai Macam Media Dalam Berkomunikasi Dengan Manusia Lainnya. Namun Saat Ini Manusia Lebih Banyak Memilih Media Yang Berbasis Audio Visual Terutama Dalam Pembuatan Videoprofile. Dimana Video Profile Sangat Dibutuhkan Perusahaan Dalam Membangun Citra Dan Juga Sebagai Media Informasi Dan Promosi, Tidak Terkecuali Pt. Ariesta Steleyna. Dalam Membangun Citra Perusahaan, Pt.Ariesta Steleyna Tidak Mau Ketinggalan Karena Melihat Antusias Masyarakat Dalam Menerima Informasi Melalui Media Audio Visual.

c. Penelitian Yang Dilakukan Oleh Eka Liesca Haryani $(2011)^{[20]}$, Yang Berjudul “ Perancangan Video Profil Sebagai Media Informasi Dan Promosi Pesantren Modern Daarul Muttaqien Cadas Sepatan Tangerang" 
Setiap Lembaga Atau Institusi Yang Ke Depannya Menginginkan Pengembangan Ke Arah Lebih Maju Secara Kualitas Maupun Kuantitasnya Pada Akhirnya Tentu Membutuhkan Sarana Penunjang Dalam Menyampaikan Informasi Program-Program Promosi Yang Telah Direncanakan, Tentunya Sarana Penunjang Tersebut Harus Terdapat Nilai Komunikatif Dan Efektif. Pesantren Modern Daarul Muttaqien Misalnya Dalam Memenuhi Target Perolehan Calon Santri Setiap Tahun Ajaran Baru, Berdasarkan Informasi Dari Pihak-Pihak Terkait Dengan Pesantren Tersebut, Sesuai Dengan Perkembangan Teknologi Informasi Yang Ada Di Sekitar Masyarakat Bahwa Hingga Sampai Saat Ini Bentuk-Bentuk Media Penunjang Dalam Menyampaikan Informasi Misi-Misi Program Promosinya Secara Image Positif Dinilai Belum Lengkap Jika Belum Terdapat Media Penunjang Dalam Bentuk Video, Karena Dari Bentuk Media Tersebut Secara Visual Selain Sebagai Sarana Penyampaian Informasi Mengenai Profile Pesantren, Media Tersebut Dapat Digunakan Sebagai Daya Tarik Dalam Melaksanakan Program Promosi Lembaga Yang Bersangkutan.

d. Penelitian yang di lakukan oleh Purwoko $(2012)^{[21]}$, yang berjudul "PERANCANGAN MEDIA VIDEO PROFILE SEBAGAI PENUNJANG PROMOSI PADA SMA ISLAMIC CENTRE TANGERANG". SMA Islamic Centre Tangerang adalah lembaga pendidikan yang di miliki oleh pemerintah kota tangerang, berdasarkan dari hasil wawancara awal yang di laksanakan pada tanggal 12 agustus 2011 bahwa hingga saat ini media-media sarana penunjang promosinya masih berupa: website,spanduk, banner dan brosur, untuk kedepannya dari pihak sekolahan menghendaki bentuk media yang dapat menampilkan tulisan,gambar dan video.

\section{KESIMPULAN}

Media video Profile SMK Kusuma Bangsa Kabupaten Tangerang sangat sekali membutuhkan video tersebut agar lebih dikenal oleh masyarakat luas dan dapat meningkat calon siswa dan siswi setiap tahunnya. Sehingga SMK Kusuma Bangsa Kabupaten Tangerang adalah salah satu yang memiliki Video Profile SMK Kusuma Bangsa Kabupaten Tangerang.

\section{DAFTAR PUSTAKA}

[1] Agustina, Prasisca. 2013 Dampak Tayangan (Drama Korea) “Boys Before Flowers" Di Televisi Dalam Perubahan Sikap Dan Perilaku Remaja. eJournal Ilmu Komunikasi. Vol. 1 No. 3, Samarinda : Universitas Mulawarman

[2] Amin. Zaenal, dan Santoso. Yudi. 2012. Pemodelan Sistem Informasi Persediaan Barang Pada PT. Nutech Pundi Arta. Jakarta : Universitas Budi Luhur

[3] Arifin, Elva. 2011. Broadcasting to Be Broadcaster. Yogyakarta : Graha Ilmu.

[4] Atmoehoetomo, Soegito. 2011. Media Audio Visual Pendidikan Dan Proses Produksi Programnya. Bandung : Alfabeta.

[5] Ayuningtyas, Melvy. 2011. Ngedit Video Dengan Adobe Premiere Pro CC, Bekasi : Dunia Komputer.

[6] Beaver, Frank. 2011. Dictionary Of Film Terms . Michigan : University of Michigan. 
[7] Megawati. 2012. Perancangan Komunikasi Visual Animasi Dokumenter R.A Kartini. Jakarta : Bina Nusantara University.

[8] Morissan. 2011. Manajemen Media Penyiaran; Strategi Mengelola dan Televisi. Jakarta : Media Grafika.

[9] Nugroho, Fajar. 2012. Cara Pintar bikin film dokumenter, Yogyakarta : Indonesia Cerdas.

[10] Nugroho, Sarwo. 2014. Teknik Dasar Videografi. Yogyakarta : Sarwo.

[11] O'Brien, James. 2012. Introducton to Information System, Jakarta : Salemba Empat. 